\title{
TREND OF PROCESSES OF BIOLOGICAL TRANSFORMATION OF NITROGEN IN RHIZOSPHERIC SOIL OF POTATO PLANTS UNDER BIOTIC AND ABIOTIC FACTORS OF CULTURE FERTILIZATION
}

\author{
V. V. Volkohon, O. M. Berdnikov, L. M. Tokmakova, K. I. Volkohon, L. V. Potapenko, \\ M. A. Zhurba, N. P. Shtanko, N. V. Lutsenko
}

In general, systems for fertilizing crops involve the use of significant amounts of mineral and organic fertilizers for the full production process of plants. But the existing agrochemical solutions aimed mainly at restoring the productive (trophic) functions and do not take into account the ecological role of soils, common factors of changes in their biological properties, and exposure of fertilizers. This is fully applies to fertilization of culture as potato, which is characterized by high demands to the level of fertilization.

In this context, the aim of our study was to investigate the environmental appropriateness of different levels and types of fertilizer and microbial preparation in potato cultivation using bioassay methods.

Materials and methods. The study was conducted in 2011-2015 on sod-podzolic soil $\left(\mathrm{pH}_{\text {soil }}\right.$ - 4.9; humus content - $1.1 \%$, mobile forms of phosphates (by Kirsanov) - $179 \mathrm{mg}$ $\mathrm{P}_{2} \mathrm{O}_{5} / \mathrm{kg}$, exchangeable potassium - 70-90 $\mathrm{mg} \mathrm{K} \mathrm{K}_{2} \mathrm{O} / \mathrm{kg}$ soil) of research field of the Institute of Agricultural Microbiology and Agroindustrial Manufacture of NAAS (Village of Progress) in cultivation of potato varieties Malych under conditions of a stationary field experiment (short rotation shift of crops: potato - oats - yellow lupine - winter rye). The scheme of the experiment included two blocks - without bacterization and using microbial preparation Biogran, each of which used different levels and types of fertilizers:

1. Without fertilizers, control;

2. $40 \mathrm{t} / \mathrm{ha}$ of manure;

3. $\mathrm{N}_{45} \mathrm{P}_{30} \mathrm{~K}_{60}$;

4. $\mathrm{N}_{90} \mathrm{P}_{60} \mathrm{~K}_{120}$;

5. $\mathrm{N}_{135} \mathrm{P}_{90} \mathrm{~K}_{180}$;

6. $40 \mathrm{t} /$ ha of manure $+\mathrm{N}_{90} \mathrm{P}_{60} \mathrm{~K}_{120}$;

7. Intermediate green manure (oil radish after winter rye).

Microbial preparation Biogran (TU 24.1-00497360-006) based on Azospirillum brasilense 410 and physiologically active substances of biohumus is recommended when cultivating potato as a factor that actively affect culture yield and product quality. 
We have previously proposed methodological principles for justification of physiologically (environmentally) appropriate standards for nitrogen fertilization of crops under determination of trends in the processes of the biological transformation of nitrogen in the root zone of plants. Appropriate method was developed. After determining the time course of nitrogen fixation activity in the root zone of crops during the growing season, depending on the norms of applied nitrogen fertilizer and comparing with the parameters of the control variant, norms under which process parameters are lower compared with control can be considered as physiologically (environmentally) appropriate.

Additional test to establish norms of use of nitrogen fertilizers in the technologies of crop cultivation, except nitrogen fixation activity, is determination of $\mathrm{N}_{2} \mathrm{O}$ emission activity in the root zone of plants. At the same time, excessive amounts of nitrogen fertilizers will provide the greatest losses of gaseous nitrogen compounds. Comparing the time course of nitrogen oxide emission and comparing them with the results of determination of nitrogen fixation activity, we can choose environmentally optimal and appropriate norms of nitrogen fertilizers. At the same time, the required amount of phosphate and potash fertilizers can be calculated by well-known principle of balance to the nitrogen.

In this regard, the experiment studied the time course of nitrogen fixation potential activity and potential biological denitrification activity (for $\mathrm{N}_{2} \mathrm{O}$ emission) in rhizospheric soil of potato plants.

Content of nitrates and ascorbic acid was measured in the product.

Registration of crop yield was performed. The obtained results underwent statistical processing using analysis-of-variance method.

Therefore, in terms of the parameters of manifestation of the functional activity of microorganisms, cultivation of potato under placement of $40 \mathrm{t} / \mathrm{ha}$ of manure, use of green manure and mineral fertilizers normally not exceeding $\mathrm{N}_{90} \mathrm{P}_{60} \mathrm{~K}_{120}$ is physiologically and ecologically appropriate on sod-podzolic soils. Use of the microbial preparation Biogran is the technologies of potato cultivation provides productivity gain ranging from $16 \%$ to $36 \%$, depending on agricultural background, as well as improvement of product quality. 